\title{
SYNOPTIC WEATHER SYSTEM ASSOCIATED WITH INFLUENCE OF THE ANTARCTIC OZONE HOLE OVER THE SOUTH OF BRAZIL ON OCTOBER, 13 ${ }^{\text {TH }, 2010}$ \\ http://dx.doi.org/10.4322/apa.2014.057
}

\begin{abstract}
Lucas Vaz Peres ${ }^{1, *}$, Natália Machado Crespo ${ }^{3}$, Otávio Krauspenhar da Silva ${ }^{3}$, Naiara Hupfer ${ }^{3}$, Vagner Anabor ${ }^{1}$, Damaris Kirsch Pinheiro ${ }^{3}$, Nelson Jorge Shuch², Neusa Maria Paes Leme ${ }^{4}$
\end{abstract}

${ }^{1}$ Universidade Federal de Santa Maria - UFSM, Av. Roraima, 1000, Camobi, Santa Maria, RS, Brazil ${ }^{2}$ Centro Regional Sul de Pesquisas Espaciais - CRS/CCR/INPE-MCTI

${ }^{3}$ Laboratório de Ciências Espaciais de Santa Maria - LACESM, Centro de Tecnologia - CT,

Universidade Federal de Santa Maria - UFSM, Av. Roraima, 1000, Camobi, Santa Maria, RS, Brazil ${ }^{4}$ Centro Regional do Nordeste - CRN/CCR/INPE-MCTI, Natal, RN, Brazil

*e-mail: lucasvazperes@gmail.com

\begin{abstract}
During spring, poor ozone air masses can come out of the Antarctic Ozone Hole and reach mid and low latitude areas like the South of Brazil forming a known phenomenon called "Secondary Effects of the Antarctic Ozone Hole". One of these phenomena was observed on October, $13^{\text {th }}, 2010$, by OMI Spectrometer over Southern Space Observatory $\left(29.42^{\circ} \mathrm{S}\right.$ and $\left.53.87^{\circ} \mathrm{W}\right)$, in São Martinho da Serra, Brazil. Stratospheric potential vorticity maps on isentropic surfaces and air mass backward trajectory using HYSPLIT model by NOAA confirmed the polar origin of the poor ozone air mass. A description of the synoptic weather system during the event was made by wind field daily average at $250 \mathrm{hPa}$ level and Omega at $500 \mathrm{hPa}$, thickness between 1000 and $500 \mathrm{hPa}$ levels and GOES 10 enhance satellite image. It was observed that the event of low ozone occurred at the same time as a high pressure pos frontal system was passing over the south of Brazil and the subtropical jet stream left the weather stable and without clouds. These actions favored the intrusion of the stratospheric air in the troposphere and helped the stratospheric air mass transport from the polar region to the South of Brazil.
\end{abstract}

Keywords: ozone, Antarctic ozone hole, potential vorticity, synoptic analysis

\section{Introduction}

The Antarctic continent shows a very low content of ozone layer during the spring of every year, the Antarctic Ozone Hole (Farman et al., 1985; Solomon, 1999). However, its effects were not limited to the Polar Region, since poor ozone air mass could come out of the polar vortex and reach mid and low latitude (Prather \& Jaffe, 1990), temporarily reducing the ozone layer. This phenomenon was first observed over South of Brazil by Kirchhoff et al. (1996). The relationship between ozone concentration and the passage of a synoptic weather system is not well known and it is being considered a new line of research for ozone (Ohring et al., 2010), which motivated this work.

\section{Methodology}

Events of influence of the Antarctic ozone hole over the south of Brazil were detected by analysis of ozone total column, obtained by an OMI Spectrometer installed in a satellite, over the Southern Space Observatory - OES/ CRS/CCR/INPE-MCTI $\left(29.42^{\circ} \mathrm{S}\right.$ and $\left.53.87^{\circ} \mathrm{W}\right)$, in São Martinho da Serra, Brazil. Days with ozone total column daily average inferior to the monthly climatological mean less 1.5 its standard deviation $(\mu-1,5 \sigma)$ were analyzed. For these days, the variation of the absolute potential vorticity on isentropic surfaces maps at $620 \mathrm{~K}$ level of potential temperature were calculated with daily parameters from NCEP/NCARreanalysis using GRADS. Air mass backward 
trajectory was obtained using HYSPLIT model by NOAA for confirmation of the polar origin of the stratospheric air. The synoptic weather system associate with wind occurrence was verified by analysis of the wind field daily average at $250 \mathrm{hPa}$ level and Omega at $500 \mathrm{hPa}$, sea level pressure and thickness between 1000 and $500 \mathrm{hPa}$ levels also using NCEP/NCAR reanalysis data with GRADS, besides GOES 10 enhanced satellite images.

\section{Results}

In this work, the example of the event that occurred on October, $13^{\text {th }}, 2010$ was used, when the ozone total column was $276.1 \mathrm{DU}$, a reduction of $5.6 \%$ over the October climatological mean which was $292,7 \pm 10.2$ DU. The air mass with poor ozone reached the South of Brazil on October, $12^{\text {th }}$, as can be observed at Figure 1, when there occurred an increase at the Absolute Potential Vorticity at $620 \mathrm{~K}$ level of potential temperature from $11^{\text {th }}$ (a) to $12^{\text {th }}(\mathrm{b})$ and higher on the $13^{\text {th }}(\mathrm{c})$, this last day registering the lowest ozone total column in the period, confirming the polar air mass origin by backward trajectory (d) and ozone image from OMI satellite (e), showing the influence of the Antarctic ozone hole over the South of Brazil.

Because of the poor ozone air mass arrival over the South of Brazil on October, $12^{\text {th }}, 2010$, the synoptic weather system was analyzed for this day, when action of the subtropical jet

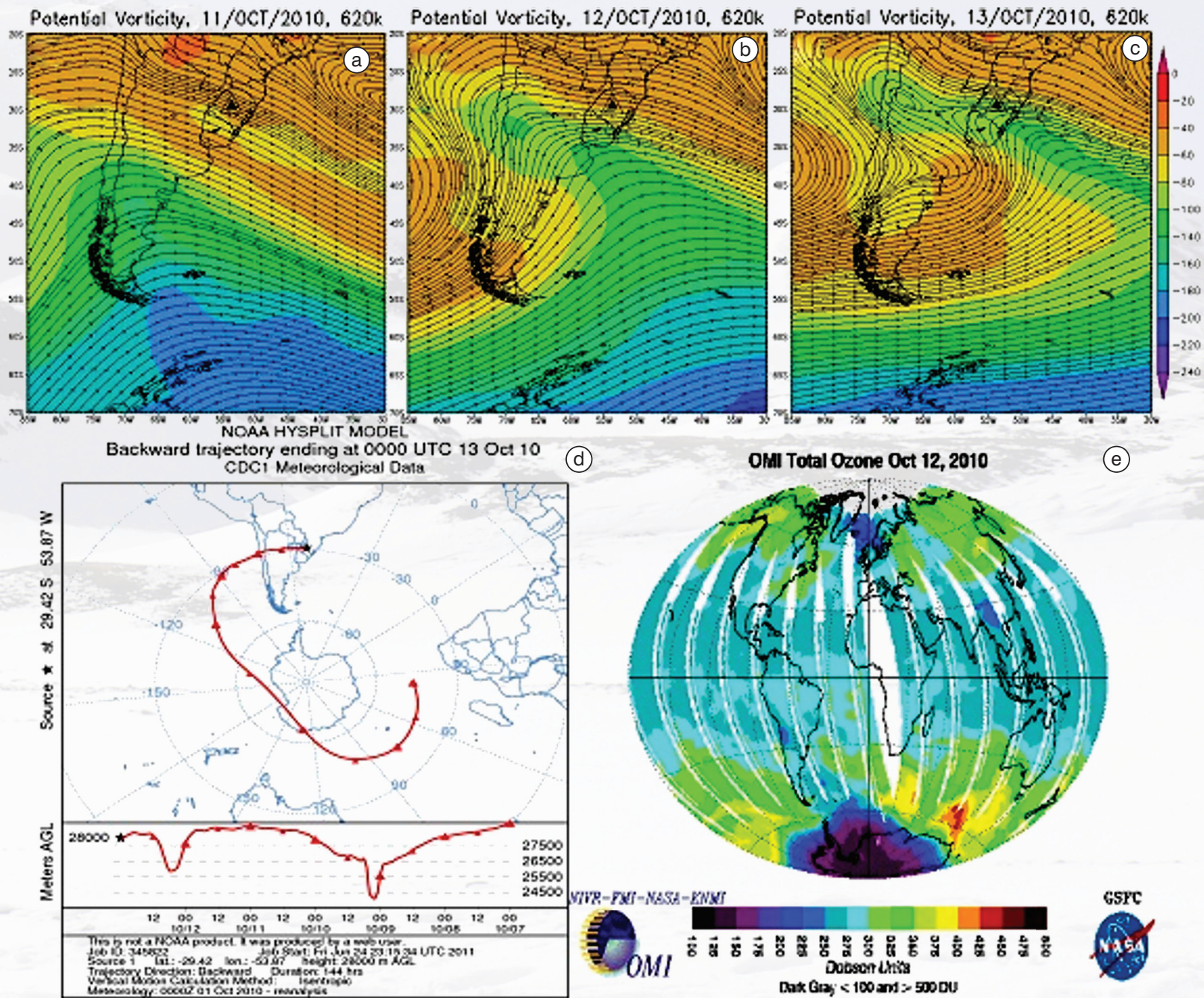

Figure 1. Potential Vorticity and Wind at $620 \mathrm{~K}$ level for $12^{\text {th }}$ (a) and $13^{\text {th }}$ (b) of October, 2010. Air mass backward trajectory (c) and OMI image (d) for $13^{\text {th }}$ and $12^{\text {th }}$, respectively.

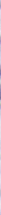


(a)
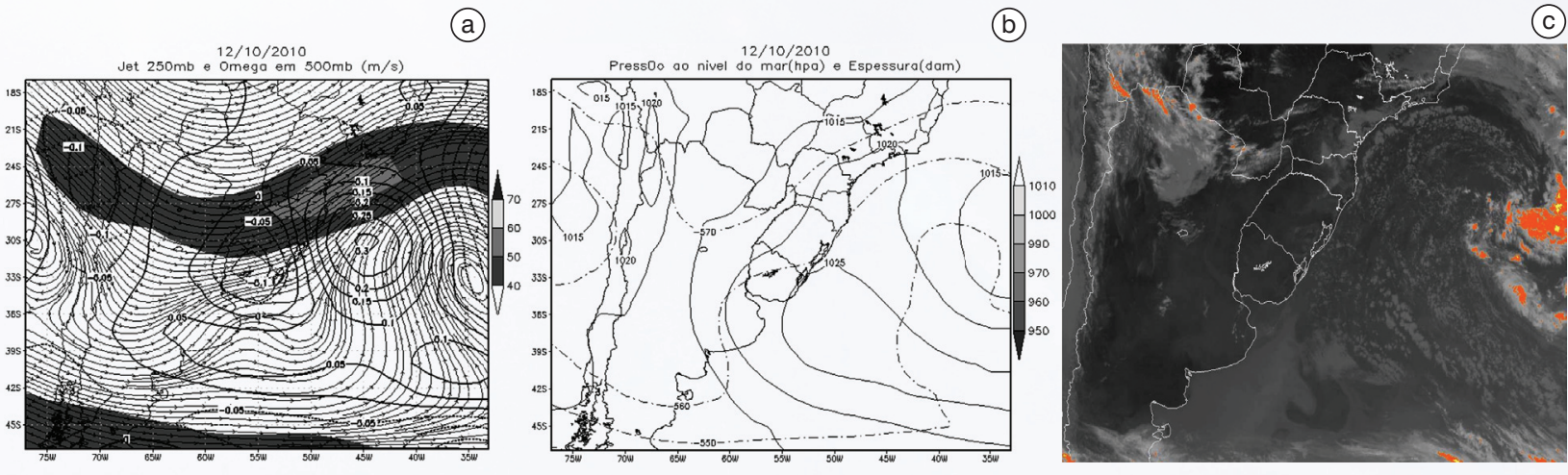

(c)

Figure 2. Wind field daily average at $250 \mathrm{hPa}$ level and Omega at $500 \mathrm{hPa}$ (a), pressure at sea level and thickness between 1000 and 500 hPa (b), and enhance GOES 10 image satellite at 12:00 (c) for October, $12^{\text {th }}, 2010$.

stream polar entry could be observed at $250 \mathrm{hPa}$ level and positive values of the Omega vertical velocity at $500 \mathrm{hPa}$ level, which was observed at Figure 2a. Furthermore, the action of an intense high pressure pos frontal system at sea level (Figure $2 b$ ) over the region was observed, getting the South of Brazil with stable weather with no cloudiness as can be observed through the satellite image (Figure 2c).

\section{Discussion and Conclusion}

The decrease in ozone total column of $5.6 \%$ less than the October climatological average which occurred on October, $13^{\text {th }}, 2010$ was due to an influence of the Antarctic ozone hole over the South of Brazil checked through the increase in Absolute Potential Vorticity indicates the polar origin of the stratospheric air mass with poor ozone (Semane et al., 2006) and confirmed by air mass backward trajectory (Gupta et al., 2007) and ozone image from OMI satellite in a manner analogous to events found by (Pinheiro et al., 2011). The synoptic weather system acting during the event was a high pressure pos frontal system at sea level, indicated subsident movement of the air over the South of Brazil, which associated with the passage of the subtropical jet stream over the region caused intrusion of the stratospheric air into the troposphere (Stohl et al., 2003). This pattern had an important role at vertical distribution and total content of ozone layer (Bukin et al., 2011), enhancing the transport of air mass from polar region towards South America and the South of Brazil and probably helped poor ozone air mass transport.

\section{Acknowledgements}

This work integrates the National Institute of Science and Technology Antarctic Environmental Research (INCT-APA) that receive scientific and financial supports of the National Council for Research and Development (CNPq process: $\mathrm{n}^{\circ}$ 574018/2008-5) and Research Support Foundation of the State of Rio de Janeiro (FAPERJ $n^{\circ}$ E-16/170.023/2008). The authors also acknowledge the support of the Brazilian Ministries of Science, Technology and Innovation (MCTI), of Environment (MMA) and Inter-Ministry Commission for Sea Resources (CIRM). Acknowledgements also to PIBIC/UFSM-CNPq/MCTI and CAPES for fellowships, NASA/TOMS and NCEP/NCAR for the data, and NOAA for HYSPLIT model.

\section{References}

Bukin, O.A.; Suan, N.; Pavlov, A.N.; Stolyarchuk, S.Y. \& Shmirko, K.A. (2011). Effect that Jet Streams Have on the Vertical Ozone Distribution and Characteristics of Tropopause Inversion Layer. Atmospheric and Oceanic Physics. 47(5): $610-618$.

Farman, J.C.; Gardiner, B.G. \& Shanklin, J.D. (1985). Large losses of total ozone in Antarctica reveal seasonal $\mathrm{ClO}_{x} / \mathrm{NO}_{x}$ interaction. Nature, 315: 207-210. 
Gupta, S.; Lal, S.; Venkataramani, S.; Rajesh, T.A. \& Acharya, Y.B. (2007). Variability in the vertical distribution of ozone over a subtropical site in India during a winter month. Journal Atmospheric Terrestrial Physics, 69: 1502-1512.

Kirchhoff, V.W.J.H.; Schuch, N.J.; Pinheiro, D.K. \& Harris, J.M. (1996). Evidence for an ozone hole perturbation at $30^{\circ}$ south. Atmospheric Environment, 33(9): 1481-1488.

Pinheiro, D.K.; Leme, N.P.; Peres, L.V. \& Kall,E. (2011). Influence of the antarctic ozone hole over South of Brazil in 2008 and 2009. National Institute of Science and Technology Antarctic Environmental Research, 1: 33-37.

Prather, M. \& Jaffe, H. (1990). Global impact of the Antarctic ozone hole: chemical propagation. Journal Geophysical Research, 95: 3413-3492.

Ohring, G.; Bojkov, R.D.; Bolle, H.J.; Hudson, R.D. \& Volkert, H. (2010). Radiation and Ozone: Catalysts for Advancing International Atmospheric Science Programs for over half a century. Space Research Today, 177.

Semane, N.; Bencherif, H.; Morel, B.; Hauchecorne, A. \& Diab, R.D. (2006). An unusual stratospheric ozone decrease in Southern Hemisphere subtropics linked to isentropic air-mass transport as observed over Irene $\left(25.5^{\circ} \mathrm{S}, 28.1^{\circ} \mathrm{E}\right)$ in midMay 2002. Atmospheric Chemistry Physics, 6: 1927-1936.

Solomon, S. (1999). Stratospheric ozone depletion: a review of concepts and history. Reviews of Geophysics, 37(3): $275-316$.

Stohl, A.; Wernli, H.; Bourqui, M.; Forster, C.; James, P.; Liniger, M.A.; Seibert, P. \& Sprenger, M. (2003). A new perspective of stratosphere-troposphere exchange. Bulletin American Meteorological Society, 84: 1565-1573.

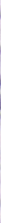

